\title{
Invertebrate herbivory on floating-leaf macrophytes at the northeast of Argentina: should the damage be taken into account in estimations of plant biomass?
}

\author{
FEDRA S. MARTÍNEZ and CELESTE FRANCESCHINI \\ Centro de Ecología Aplicada del Litoral - CECOAL(CCT Nordeste-CONICET- \\ UNNE), Ruta 5, Km 2.5, (3400) Corrientes, Argentina
}

Manuscript received on May 30, 2016; accepted for publication on September 6, 2017

\begin{abstract}
We assessed the damage produced by invertebrate herbivores per leaf lamina and per $\mathrm{m}^{2}$ of populations floating-leaf macrophytes of Neotropical wetlands in the growth and decay periods, and assessed if the damage produced by the herbivores should be taken into account in the estimations of plant biomass of these macrophytes or not. The biomass removed per lamina and per $\mathrm{m}^{2}$ was higher during the growth period than in decay period in Nymphoides indica and Hydrocleys nymphoides, while Nymphaea prolifera had low values of herbivory in growth period. During decay period this plant is only present as vegetative propagules. According to the values of biomass removed per $\mathrm{m}^{2}$ of $N$. indica, underestimation up to $17.69 \%$ should be produced in cases that herbivory do not should be taking account to evaluate these plant parameters on this macrophyte. Therefore, for the study of biomass and productivity in the study area, we suggest the use of corrected lamina biomass after estimating the biomass removed by herbivores on $N$. indica. The values of damage in $N$. indica emphasize the importance of this macrophyte as a food resource for invertebrate herbivores in the trophic networks of the Neotropical wetlands.
\end{abstract}

Key words: plant damage, herbivores, Nymphoides, Nymphaea.

\section{INTRODUCTION}

Recent studies from wetlands in the Northern Hemisphere, mainly in temperate regions show that the herbivory in freshwater macrophytes is significant and can reduce the plant biomass (Bakker et al. 2016) and plant abundance (Wood et al. 2017) by 44-48\%. However, these generalizations do not consider the effect and the role of invertebrate herbivores on macrophytes of Neotropical wetlands, because there is little

Correspondence to: Fedra Solange Martínez

E-mail: fedrasolange@yahoo.com.ar evidence of herbivory in these environments (Esteves 2011). The Neotropical region contains the greatest concentration of species richness and biodiversity (Wantzen et al. 2006, Nunes et al. 2016) and a great amount of aquatic environments compared to other regions (Foottit and Adler 2009). Thus, the effect of invertebrate herbivores on freshwater macrophytes in Neotropical wetlands could be quite different from the pattern described for wetlands in the Northern Hemisphere.

In the Neotropical wetlands, quantifications of the amount of herbivore damage and the effect on macrophyte populations are scarce and only refer 
to free floating macrophytes (Adis and Junk 2003, Poi de Neiff and Casco 2003, Sosa et al. 2007, Franceschini et al. 2010, 2013, Braga et al. 2013, Martinez et al. 2013). These studies show that invertebrate herbivores can also feed high amounts of freshwater macrophyte biomass and that the abundance and magnitude of the damage caused by herbivores vary significantly between the growth and decay periods of the macrophyte populations (Braga et al. 2013, Franceschini et al. 2010, 2013).

Among macrophytes, floating-leaf macrophytes can reach high coverage and abundance in freshwater environments across the world (Wiersema 1987, Brock and Van Der Velde 1996). Among the floatingleaf macrophyte species, Hydrocleys nymphoides Willd. Buchenau (Alismataceae), Nymphoides indica (L.) Kuntze (Menyanthaceae) and Nymphaea prolifera Wiersema (Nymphaeaceae) have high abundance and coverage in Neotropical wetlands (Wiersema 1987, Palma-Silva et al. 2008). While $N$. indica is native to tropical and subtropical America, Asia and Australia (Oenduff 1969), $H$. nymphoides and Nymphaea prolifera are native only to the Neotropic areas and they were introduced in wetlands of the United States, Australia and New Zealand (Wiersema 1987, Haynes 2000). $H$. nymphoides and $N$. indica have been mentioned as weeds in the irrigation channels and cultivated rice paddies (Lallana 2005).

One of the special features of floating-leaf macrophytes is that their leaves develop first below the water line and then grow up to the water surface, as a result, they can be consumed by aquatic and semi-aquatic invertebrate herbivores (Cronin et al. 1998). Despite the taxa of herbivores, the level of damage and the role played by floatingleaf macrophyte herbivores in wetlands of the Northern Hemisphere are well studied, especially during the growth period (Van Der Velde et al. 1982, Cronin et al. 1998, Nachtrieb et al. 2011), there is little information in this regard for the Neotropical wetlands. In these wetlands, floating- leaf macrophytes are known to account for $87 \%$ of the diet of Orthopterans (Capello et al. 2012), and they can also be consumed by Curculionidae (Wibmer 1989). However, the impact of herbivory damage on the biomass of the floating-leaf macrophyte populations, the biomass consumed by invertebrate herbivores in the growth and decay periods, and therefore the role of these herbivores in wetlands inhabited by these macrophytes, remains unclear. Recent investigations in the study area show that herbivores can reach up to $60 \%$ of the total invertebrates in floating-leaf macrophytes, especially in the growth period (Martínez F.S. et al., unpublished data, Franceschini et al. 2016). Thus, it is important to determine if invertebrate herbivores remove a low amount of leaf biomass of these macrophytes (Hunt-Joshi et al. 2004) or if the leaf biomass removed is high, which could imply that herbivores are important consumers of the living plant tissue in the wetland food webs (Franceschini et al. 2010, Braga et al. 2013). For this reason, the herbivory damage should be taken into account in the estimations of plant biomass and productivity. Abundance and composition of invertebrate herbivores vary according to the temperatures and hydroperiod in the Neotropical wetlands, obtaining the higher herbivore abundances in the growth period of the plant populations (Capello et al. 2013). Likewise, the plant biomass of macrophyte species varies significantly between the growth and decay periods, reducing the biomass of macrophytes in the decay period by up to $50 \%$ (Neiff et al. 2008). These differences in plant biomass imply that the food resource available to herbivores also differs in quantity and quality (Peeters et al. 2007), whereby, it would be expected that herbivory would also differ between these periods. In addition, most studies of herbivory in floating-leaf macrophytes focus only on the leaf lamina and give information about the biomass or area damaged by herbivores per leaf lamina (Van Der Velde et al. 1982, 1985, Cronin et al. 1998). However, as leaf densities vary 
considerably between growth and decay periods and macrophyte species, damage produced by herbivores per square meter is an indispensable tool to achieve a complete understanding of the herbivory process in macrophyte populations.

The aim of this paper is to: 1) quantify and compare the damage produced by invertebrate herbivores per leaf lamina and per $\mathrm{m}^{2}$ of floating-leaf macrophytes in the growth and decay periods, and 2) assess if the damage produced by the herbivores should be taken into account in the estimations of plant biomass of these macrophytes or not.

In relation to the total of the invertebrates found in floating-leaf macrophytes of the study area, herbivores can reach a high abundance, mainly during the growth period. Therefore, our hypothesis is that invertebrate herbivory is significant in floating-leaf macrophytes and that the damage by herbivores should be taken into account in estimations of plant biomass of these macrophytes.

\section{MATERIALS AND METHODS}

\section{STUDY SITES}

Samplings were carried out in two wetlands in Northeastern Argentina: Site A (2729'1.43”S, $\left.58^{\circ} 45^{\prime} 0.95^{\prime} \mathrm{W}\right)$ and Site B $\left(27^{\circ} 22^{\prime} 0.95^{\prime} \mathrm{S}\right.$, $58^{\circ} 20^{\prime} 3.79^{\prime \prime} \mathrm{W}$ ), in the growth period and in the decay period of plant populations. Since the abundance of herbivorous insects can vary significantly according to the successional stage of the vegetation (Silva et al. 2012), these wetlands were selected because the studied macrophytes were present in undisturbed populations, at a late successional stage and with a coverage of 30 to $40 \%$ of the water surface. Site A covers approximately 70 ha and supports populations of $H$. nymphoides and $N$. prolifera. Site B covers an extension of 4.91 ha and supports populations of $N$. indica; $N$. prolifera was also present in this site but it was very scarce. The climate of this area is subtropical, with warm summers and mild winters, occasional frost days (frequency of 0.25 days/year) and temperatures not dropping lower than $-5^{\circ} \mathrm{C}$ (Bruniard 1996). Sampling dates were chosen to follow the phenology of the floating-leaf macrophytes in the study area: the decay period, in winter (June to August) and the growth period, in summer (February to March). In the period under study, $N$. prolifera had no leaves during the decay period, but vegetative propagules were recorded in this period, which coincides with that mentioned by Wiersema (1987). Leaves of H. nymphoides and $N$. indica were present in both periods.

\section{SAMPLING DESIGN TO ASSESS HERBIVOROUS DAMAGE PER LAMINA AND PER M²}

To measure herbivorous damage on leaves, we sampled a total of 15 macrophyte species- habitatgrowth period combinations (2 macrophyte species x 3 habitats $x 2$ growth periods +1 macrophyte x 3 habitats $x 1$ growth period), and collected 10 leaves of different plants from each sampling combination, for a total of 150 sampled leaves. The habitats sampled were the proximal edge, the centre and the distal edges of the floating matt, which were separated by a distance of $100 \mathrm{~m}$, to ensure the randomness of the samples. We chose these three habitats because they represent three heterogeneous zones in floating-leaf macrophyte populations, due to the coexisting vegetation and the location in the wetland.

The herbivore damage on leaves estimated in discrete samples, gives a valuable measure of herbivory, and such estimates are easy to carry out (Franceschini et al. 2010).

According to Labandeira (1998), two categories of damage, surface abrasion and holes, were distinguished on the lamina of floating-leaf macrophytes. The surface abrasions are caused when tissues are not completely removed, and the most basal tissue persists in the affected areas of 
leaves. The holes involve complete removal of tissues.

Herbivory was measured at the level of leaf lamina and per square meter $\left(\mathrm{m}^{2}\right)$ of vegetation. To assess herbivory at the level of leaf lamina, digital images of the sampled leaves were taken in the laboratory. The area of leaf lamina was measured and the area damaged by herbivores per leaf lamina was quantified $\left(\mathrm{cm}^{2}\right)$, considering holes and surface abrasion separately. The software used for processing the digital images was ImageJ 1.44 (Rasband 2016).

Biomass removed by herbivores (surface abrasions and holes) was calculated indirectly using the damaged lamina area data (Franceschini et al. 2010). Surface abrasion was assessed by the difference between the area with this type of damage and the same size area without damage. The biomass was calculated on the basis of the mean weight of 30 circles of $0.196 \mathrm{~cm}^{2}$ with surface abrasion and the same number of circles of the same size from undamaged areas using the following equation

$b_{s}=\frac{\sum a d \cdot(W n-W d)}{\frac{a_{s}}{N}}$

where $\mathrm{b}_{\mathrm{s}}$ is surface abrasion biomass $(\mathrm{g}), \mathrm{ad}$ is the damaged area by surface abrasion $\left(\mathrm{cm}^{2}\right), a_{s}$ is area of a circle $\left(\mathrm{cm}^{2}\right), W n$ is the mean weight of undamaged circles $(\mathrm{g}), \mathrm{Wd}$ is the mean weight of damaged circles with surface abrasion $(\mathrm{g})$, and $N$ is the total number of leaves.

The average weight of undamaged circles was used to calculate the biomass removed by holes because tissues are removed completely in the affected areas; the following equation was used to calculate the biomass removed by this damage

$\frac{\mathbf{b}_{\mathbf{h}}=\sum a d \cdot W n}{\frac{a_{s}}{N}}$

where $b_{h}$ is hole biomass, $a d$ is the area damaged by holes $\left(\mathrm{cm}^{2}\right), a_{s}$ is the area of a circle $\left(\mathrm{cm}^{2}\right), W n$ is the mean weight of undamaged circles $(\mathrm{g})$, and $N$ is the total number of leaves.

We assessed the total biomass removed per lamina (holes + abrasion). The dry weight per lamina was obtained by drying at $105^{\circ} \mathrm{C}$ for 72 hours and then laminas were individually weighed to obtain the "uncorrected lamina biomass". Since herbivore damage to discrete samples makes it impossible to measure undamaged lamina biomass directly (Franceschini et al. 2010), we added the total biomass removed per lamina (holes + abrasion) to the "uncorrected lamina biomass" to obtain the "corrected lamina biomass" (Fig. 1a, b).

In order to quantify leaf density and the biomass removed by herbivores per $\mathrm{m}^{2}$ in floatingleaf macrophyte populations, samples of green leaves were also taken within a $0.33 \mathrm{~m}^{2}$ aluminium ring in each of the 15 macrophyte species- habitatgrowth period combinations. Three replications were taken and to ensure random samples, each ring was separated by a distance of $100 \mathrm{~m}$. Within the rings, we quantified leaf density (number of leaves per $\mathrm{m}^{2}$ ). Leaves were then removed by cutting off petioles at ground level at the bottom of the lakes.

In the laboratory, laminas from the field including damage were dried and were directly weighed to obtain "the uncorrected lamina biomass per $\mathrm{m}^{2}$ " $\left(\mathrm{g}\right.$ per $\left.\mathrm{m}^{2}\right)$. Dry weight was obtained at $105{ }^{\circ} \mathrm{C}$. Removed lamina biomass by herbivores per $\mathrm{m}^{-2}(\mathrm{~g})$ was calculated by multiplying the total removed biomass per lamina (equation $1+$ equation 2) by the leaf densities of the different growth periods in each macrophyte species. Because with herbivore damage of discrete samples it is not possible to measure directly undamaged lamina biomass per $\mathrm{m}^{-2}$ (Franceschini et al. 2010), we added to the uncorrected lamina biomass $\left(\mathrm{g}\right.$ per $\mathrm{m}^{-2}$ ) the values of removed lamina biomass per $\mathrm{m}^{2}$ to obtain the corrected lamina biomass per $\mathrm{m}^{2}$ (g) (Fig. 1c, d). 


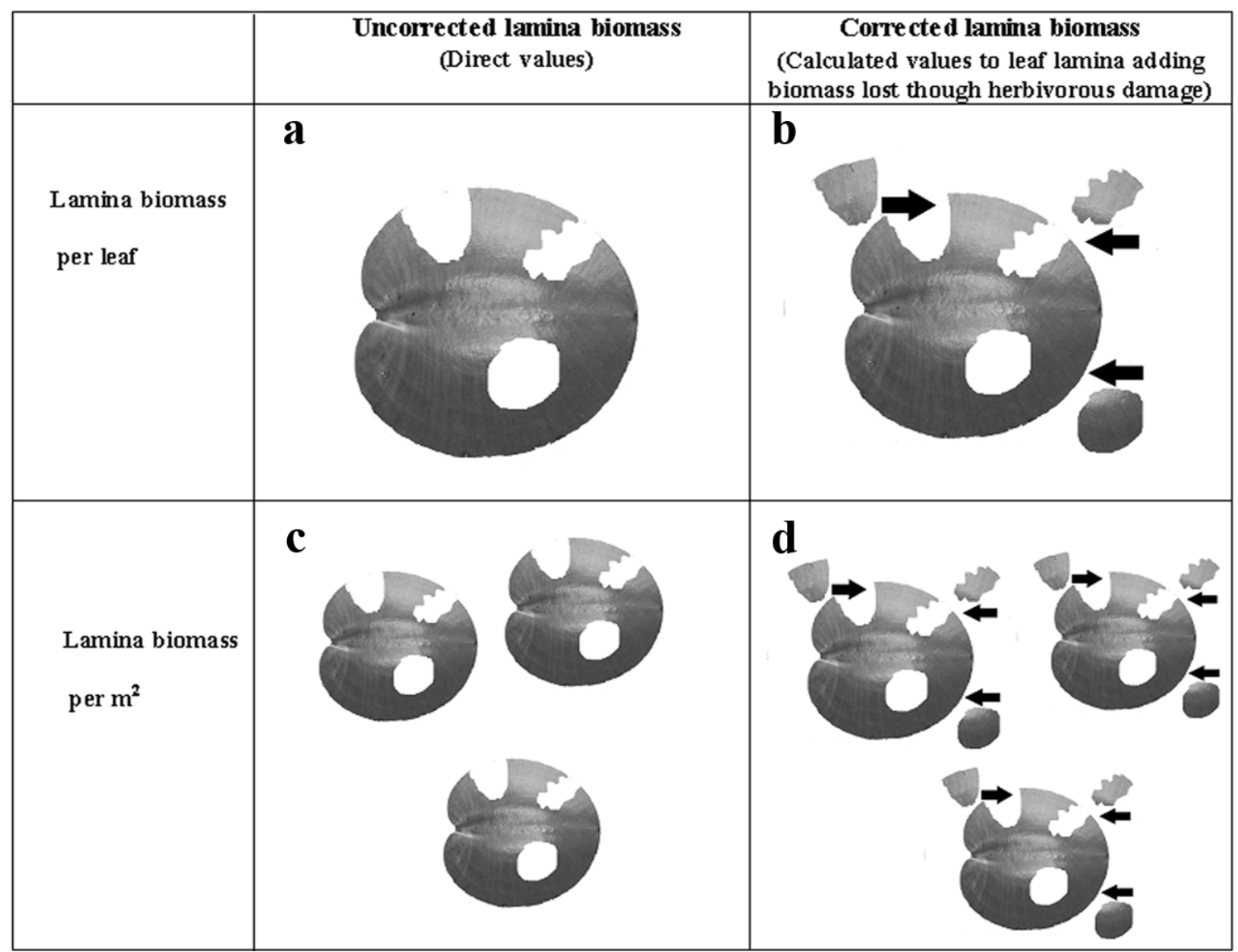

Figure 1 - Uncorrected and corrected lamina biomass in freshwater macrophytes. The uncorrected lamina biomass is the weight of the lamina measured directly, without including herbivorous damage. The corrected lamina biomass is the weight of the lamina adding herbivorous damage. a: Uncorrected lamina biomass per leaf; $\mathbf{b}$ : Corrected lamina biomass per leaf; c: Uncorrected lamina biomass per $\mathrm{m}^{2 ;} \mathbf{d}$ : Corrected lamina biomass per $\mathrm{m}^{2}$.

Lamina biomass removed by herbivores per $\mathrm{m}^{2}$ was expressed as percentage using values of corrected lamina biomass per $\mathrm{m}^{2}$. Leaf area, leaf biomass and leaf density were measured as indicators of food resource available for invertebrate herbivores in different macrophyte species and growth periods.

\section{STATISTICAL PROCEDURE}

All data were tested for normality (Shapiro-Wilk tests) and homogeneity of variance (Levene's test). Data that failed to meet the requirements of normality and homogeneity after transformation were analysed using non-parametric statistics. The differences between sampling dates in the total damaged lamina by herbivores, total biomass removed per lamina and per $\mathrm{m}^{2}$, uncorrected and corrected lamina biomass and lamina biomass removed by herbivores per $\mathrm{m}^{2}$ were tested by one-way ANOVAs with post hoc Tukey tests. The differences in sampling dates between types of damage produced by herbivores, lamina areas, leaf density were tested by KruskalWallis tests, with post hoc multiple comparison tests. To assess percentage of lamina biomass removed by herbivores per leaf and per $\mathrm{m}^{2}$ between species of macrophytes we used one-way ANOVAs with post hoc Tukey tests. To meet the assumptions of normality of dates, the percentages of herbivory were transformed an arcsine of the square root of 
the proportion. All analyses were conducted using software Infostat version 2016 (Di Rienzo et al. 2016).

\section{RESULTS}

HERBIVORY PER LEAF LAMINA AND $\mathrm{M}^{2}$ OF VEGETATION IN GROWTH AND DECAY PERIODS

Considering the food resource available for herbivores per leaf, the lamina area was significantly higher in the growth period than in the decay period on $H$. nymphoides $(\mathrm{H}=32.06, p<$ $0.0001)$ and $N$. indica $(\mathrm{H}=30.90, p<0.0001) . H$. nymphoides offered to the herbivores significantly more leaf biomass in the growth period $(\mathrm{H}=32$. $06, p<0.0001)$ than in the decay period, while $N$. indica showed no significant differences between these periods $(\mathrm{H}=3.2, p=0.0734)$. In the growth period, $N$. prolifera offered more food resources to herbivores as it showed 8 to 15 times more of the leaf biomass and twice as much of the leaf lamina area than the other two macrophyte species.

The total area damaged by herbivores per lamina (surface abrasions + holes) on $H$. nymphoides was significantly higher $(\mathrm{H}=11.56, p=0.0005)$ during the growth period than in the decay period and the damage represented up to $3.84 \%$ of the leaf lamina area. Similarly, on $N$. indica significant differences were found between periods $(\mathrm{H}=19.02, p<0$. 0001) in the total area damaged per lamina (surface abrasions + holes). The total area damaged per lamina was 4.5 times higher in the growth period than in the decay period (Table I).

The total biomass removed by herbivores per lamina (surface abrasions + holes) was significantly higher during the growth period than in the decay period on $H$. nymphoides $(\mathrm{H}=10.34, p=0.0011)$ and $N$. indica $(\mathrm{H}=19.54, p<0.0001)$. Total biomass removed per lamina on $H$. nymphoides was three times more in the growth period than in the decay period, while on $N$. indica it was more than double in the growth period than in the decay period.
Herbivory on $N$. prolifera leaves was low, values of lamina area damaged and biomass removed per lamina were lower than for $N$. indica and $H$. nymphoides in the growth period (Table I).

Considering the food resource available for herbivores in plant populations, leaf density per $\mathrm{m}^{2}$ of $H$. nymphoides did not vary significantly $(\mathrm{H}=0.43, p=0.700)$ between periods, while on $N$. indica it did vary significantly $(\mathrm{H}=41.82, p=$ 0.0029 ) between periods. In the growth period, leaf density per $\mathrm{m}^{2}$ of $N$. indica was eight times higher than in the decay period. In the growth period, $N$. prolifera showed an intermediate leaf density per $\mathrm{m}^{2}$ in comparison to the other two macrophytes. The percentage of attacked leaves was high in the three macrophyte species, especially in growth period (Table I).

Lamina biomass removed per $\mathrm{m}^{2}(\mathrm{~g})$ by herbivores was significantly higher in the growth period than in the decay period on $H$. nymphoides $\left(\mathrm{F}_{1,4}=18.56, p=0.013\right)$ and $N$. indica $\left(\mathrm{F}_{1,4}=14.91\right.$, $p=0.018)$ plant populations. On $H$. nymphoides herbivores removed four times more biomass per $\mathrm{m}^{2}(\mathrm{~g})$ in the growth period than in the decay period, whereas on $N$. indica, herbivores removed forty six times more biomass per $\mathrm{m}^{2}(\mathrm{~g})$ in the growth period than in the decay period. In the growth period, herbivory values per $\mathrm{m}^{2}$ on $N$. prolifera were intermediate in relation to the other two species (Table I).

Considering the types of damage produced by herbivores on leaves in the growth period, biomass removed by surface abrasion was significantly higher than holes $(\mathrm{H}=17.14, p=$ 0.0001 ) on $H$. nymphoides, whereas on $N$. indica and $N$. prolifera holes were significantly higher $(\mathrm{H}=28.64, p<0.0001 ; \mathrm{H}=11.36, p=0.0007$, respectively) than surface abrasion (Fig. 2). In the decay period significant differences were only observed $(\mathrm{H}=6.35, p=0.0113)$ between types of damage for $N$. indica, that is, damage by holes was ten times higher than damage by surface 
TABLE I

Area $\left(\mathrm{cm}^{2}\right)$ and biomass $(\mathrm{g})$ of the leaf lamina and total damage (surface abrasions + holes) produced by invertebrate herbivores per lamina in leaves of Hydrocleys nymphoides and Nymphoides indica in growth and decay period, and Nymphaea prolifera in growth period. Values of herbivory are expressed as damaged area $\left(\mathrm{cm}^{2}\right.$ per lamina and per $\left.\mathrm{m}^{2}\right)$ and biomass removed ( $g$ per lamina and per $\mathrm{m}^{2}$ ): mean \pm standard deviation. \% removed per lamina. Different letters indicate means statistically different between sampling dates.

\begin{tabular}{|c|c|c|c|c|c|c|c|c|}
\hline & & \multicolumn{4}{|c|}{ Leaf lamina } & \multicolumn{3}{|c|}{ Plant population } \\
\hline & $\begin{array}{l}\text { Growth } \\
\text { periods }\end{array}$ & Area & Biomass & $\begin{array}{c}\text { Damaged } \\
\text { area }\end{array}$ & $\begin{array}{l}\text { Biomass } \\
\text { removed }\end{array}$ & $\begin{array}{c}\text { Leaf density } \\
\text { (number per } \\
\mathbf{m}^{2} \text { ) }\end{array}$ & $\begin{array}{c}\text { Damaged } \\
\text { leaves (\%) }\end{array}$ & $\begin{array}{c}\text { Lamina } \\
\text { biomass } \\
\text { removed per } \\
\text { m }^{2}(\mathrm{~g})\end{array}$ \\
\hline \multirow{2}{*}{$\begin{array}{l}\text { Hydrocleys } \\
\text { nymphoides }\end{array}$} & Growth & $\begin{array}{l}58.28^{\mathrm{a}} \\
\pm 17.66\end{array}$ & $\begin{array}{l}0.356^{\mathrm{a}} \\
\pm 0.108\end{array}$ & $\begin{array}{c}2.24^{\mathrm{b}} \\
\pm 2.22 \\
3.84 \%{ }^{\mathrm{a}}\end{array}$ & $\begin{array}{l}0.009^{\mathrm{b}} \\
\pm 0.011 \\
2.54 \%^{\mathrm{a}}\end{array}$ & $\begin{array}{l}54.25^{\mathrm{a}} \\
\pm 15.95\end{array}$ & $\begin{array}{l}86.67^{\mathrm{a}} \\
\pm 5.77\end{array}$ & $\begin{array}{c}0.50^{\mathrm{a}} \\
\pm 0.15 \\
3.62 \%{ }^{\mathrm{a}}\end{array}$ \\
\hline & Decay & $\begin{array}{l}29.08^{\mathrm{b}} \\
\pm 10.59\end{array}$ & $\begin{array}{l}0.178^{\mathrm{b}} \\
\pm 0.065\end{array}$ & $\begin{array}{c}0.73^{\mathrm{a}} \\
\pm 1.11 \\
2.50 \%^{\mathrm{b}}\end{array}$ & $\begin{array}{l}0.003^{\mathrm{a}} \\
\pm 0.004 \\
1.65 \%^{\mathrm{a}}\end{array}$ & $\begin{array}{l}45.21^{\mathrm{a}} \\
\quad \pm 0\end{array}$ & $\begin{array}{c}50^{\mathrm{b}} \\
\pm 26.46\end{array}$ & $\begin{array}{c}0.14^{\mathrm{b}} \\
\pm 0 \\
2.62 \%\end{array}$ \\
\hline \multirow{2}{*}{$\begin{array}{l}\text { Nymphoides } \\
\text { indica }\end{array}$} & Growth & $\begin{array}{l}66.72^{\mathrm{a}} \\
\pm 20.11\end{array}$ & $\begin{array}{l}0.184^{\mathrm{a}} \\
\pm 0.071\end{array}$ & $\begin{array}{c}9.06^{\mathrm{b}} \\
\pm 7.83 \\
13.59 \%^{\mathrm{b}} \\
\end{array}$ & $\begin{array}{c}0.034^{\mathrm{b}} \\
\pm 0.031 \\
15.60 \%{ }^{\mathrm{b}}\end{array}$ & $\begin{array}{l}176.81^{\mathrm{a}} \\
\pm 77.6\end{array}$ & $\begin{array}{c}100^{\mathrm{a}} \\
\pm 0.00\end{array}$ & $\begin{array}{c}6.01^{\mathrm{a}} \\
\pm 2.64 \\
17.69 \%^{\mathrm{b}} \\
\end{array}$ \\
\hline & Decay & $\begin{array}{l}37.4^{\mathrm{b}} \\
\pm 7.73\end{array}$ & $\begin{array}{l}0.150^{\mathrm{a}} \\
\pm 0.040\end{array}$ & $\begin{array}{c}2.03^{\mathrm{a}} \\
\pm 2.74 \\
5.43 \%{ }^{\mathrm{a}}\end{array}$ & $\begin{array}{l}0.007^{\mathrm{a}} \\
\pm 0.010 \\
4.18 \%{ }^{\mathrm{a}}\end{array}$ & $\begin{array}{l}20.09^{\mathrm{b}} \\
\pm 3.48\end{array}$ & $\begin{array}{l}90.00^{\mathrm{a}} \\
\pm 17.32\end{array}$ & $\begin{array}{l}0.13^{\mathrm{b}} \\
\pm 0.02 \\
3.25 \%\end{array}$ \\
\hline $\begin{array}{l}\text { Nymphaea } \\
\text { prolifera }\end{array}$ & Growth & $\begin{array}{l}136.82 \\
\pm 46.07\end{array}$ & $\begin{array}{c}2.900 \\
\pm 0.977\end{array}$ & $\begin{array}{c}1.83 \\
\pm 1.55 \\
1.34 \%{ }^{\mathrm{a}}\end{array}$ & $\begin{array}{c}0.032 \\
\pm 0.030 \\
1.10 \%{ }^{\mathrm{a}}\end{array}$ & $\begin{array}{c}86.40^{\mathrm{a}} \\
\pm 46.82\end{array}$ & $\begin{array}{l}93.33^{\mathrm{a}} \\
\pm 5.77\end{array}$ & $\begin{array}{l}2.80^{\mathrm{a}} \\
\pm 1.52 \\
6.52 \%\end{array}$ \\
\hline
\end{tabular}

abrasions (Fig. 3). Biomass removed by surface abrasions were produced by adults of Lixini sp (Coleoptera: Curculionidae), nymphs of Marellia remipes (Orthoptera: Acrididae) and Omalonyx sp (Gasteropoda: Succineidae). Holes were produced by adults of $M$. remipes, larvae of Pyrallidae and Noctuidae (Lepidoptera) and Pomacea canaliculata (Gasteropoda: Ampullaridae). Other herbivores such as Rhopalosiphum nymphaeae (Hemiptera: Aphididae) were also observed on H. nympoides.

\section{HERBIVORE DAMAGE, THE UNCORRECTED} LAMINA BIOMASS AND THE CORRECTED LAMINA BIOMASS

Herbivory in leaf lamina and in plant population was notably high on $N$. indica, mainly in the growth period. In fact, $N$. indica had a significantly higher percentage of biomass removed per lamina $\left(\mathrm{F}_{2,87}=\right.$ $36.32, p<0.0001)$ and percentage of lamina biomass removed per $\mathrm{m}^{2}\left(\mathrm{~F}_{2,6}=20.53, p=0.0021\right)$ than the other floating-leaf macrophyte species (Table I). According to the values of biomass removed per lamina and lamina biomass removed per $\mathrm{m}^{2}$ of $N$. indica, subestimations up to $15.60 \%$ of the leaf lamina biomass and $17.69 \%$ of the leaf biomass per $\mathrm{m}^{2}$ should be considered in cases in which herbivory is not taking into account the evaluation of these plant parameters on this macrophyte.

Herbivory per leaf lamina on $H$. nymphoides and $N$. prolifera was low, so subestimations of the leaf lamina biomass should not exceed $2.54 \%$. According to the values of lamina biomass removed 


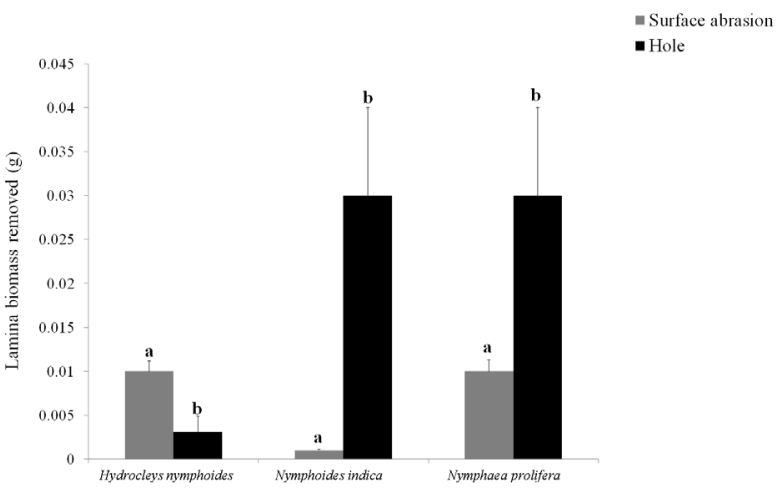

Figure 2 - The lamina biomass removed (g) by surface abrasion and holes per leaf lamina on floating-leaf macrophytes in the growth period. Different letters indicate means statistically different between sampling dates.

per $\mathrm{m}^{2}$, up to $6.52 \%$ of the leaf biomass per $\mathrm{m}^{2}$ should be subestimated in $N$. prolifera, whereas on $H$. nymphoides these values should not exceed $3.62 \%$ (Table I).

On $H$. nymphoides, which had low herbivorous damage, significant differences were observed between periods in the uncorrected lamina biomass $(\mathrm{H}=32.06, p<0.0001)$, which is the biomass measured directly, without including herbivorous damage. Similar results were obtained when the comparison was made using the corrected lamina biomass $(\mathrm{H}=$ 32. $65, p<0.0001$ ), which is the biomass that includes herbivorous damage (Figs. 1 and 4).

On $N$. indica, the uncorrected lamina biomass did not vary significantly between periods $(\mathrm{H}=$ 3.17, $p=0.0749$ ). Results were different when the comparison was made using the corrected lamina biomass, which includes herbivorous damage (Figs. 1 and 4). In fact, corrected lamina biomass of $N$. indica showed significant differences between periods $(\mathrm{H}=11.02, p=0.0009)$. The reason why different results are shown, whether the uncorrected or corrected lamina biomass is used in the comparison, is that a considerably high biomass of this macrophyte is removed by herbivores.

Estimations of leaf biomass during the growth period may be notably underestimated for $N$. indica

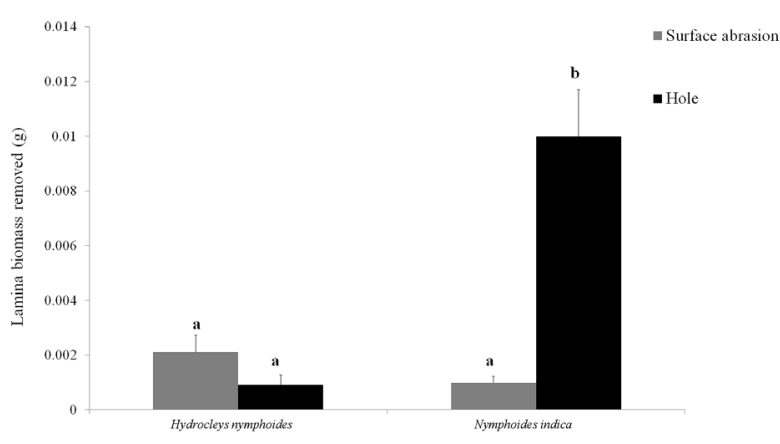

Figure 3 - The lamina biomass removed ( $g$ ) by surface abrasion and holes per leaf lamina on floating-leaf macrophytes in decay period. Different letters indicate means statistically different between sampling dates.

$(15.60 \%)$ in cases that the uncorrected lamina biomass is used instead of the corrected lamina biomass (Figure 5).

\section{DISCUSSION}

HERBIVORY ON FLOATING-LEAF MACROPHYTES IN GROWTH AND DECAY PERIODS

The great damage produced by herbivores in $H$. nymphoides and $N$. indica in the growth period could be related to the highest availability of resources per leaf and per $\mathrm{m}^{2}$ in these macrophytes (Coley et al. 1985). In addition, abundance of invertebrate herbivores is higher in growth than in decay period in the study area (Franceschini et al. 2011, 2013, Martínez F.S. et al., unpublished data). Higher food resource in the growth period than in the decay period is consistent with the results found for Nymphoides peltata in the Northern Hemisphere (Van Der Velde et al. 1979).

Higher biomass removed per lamina and per $\mathrm{m}^{2}$ in the growth period found in $H$. nymphoides and $N$. indica is consistent with the results found for E. crassipes (Franceschini et al. 2010,). In fact, E. crassipes biomass removed per lamina and per $\mathrm{m}^{2}$ was 3.5 and 2.8 times higher in the growth period than in decay period, respectively. 


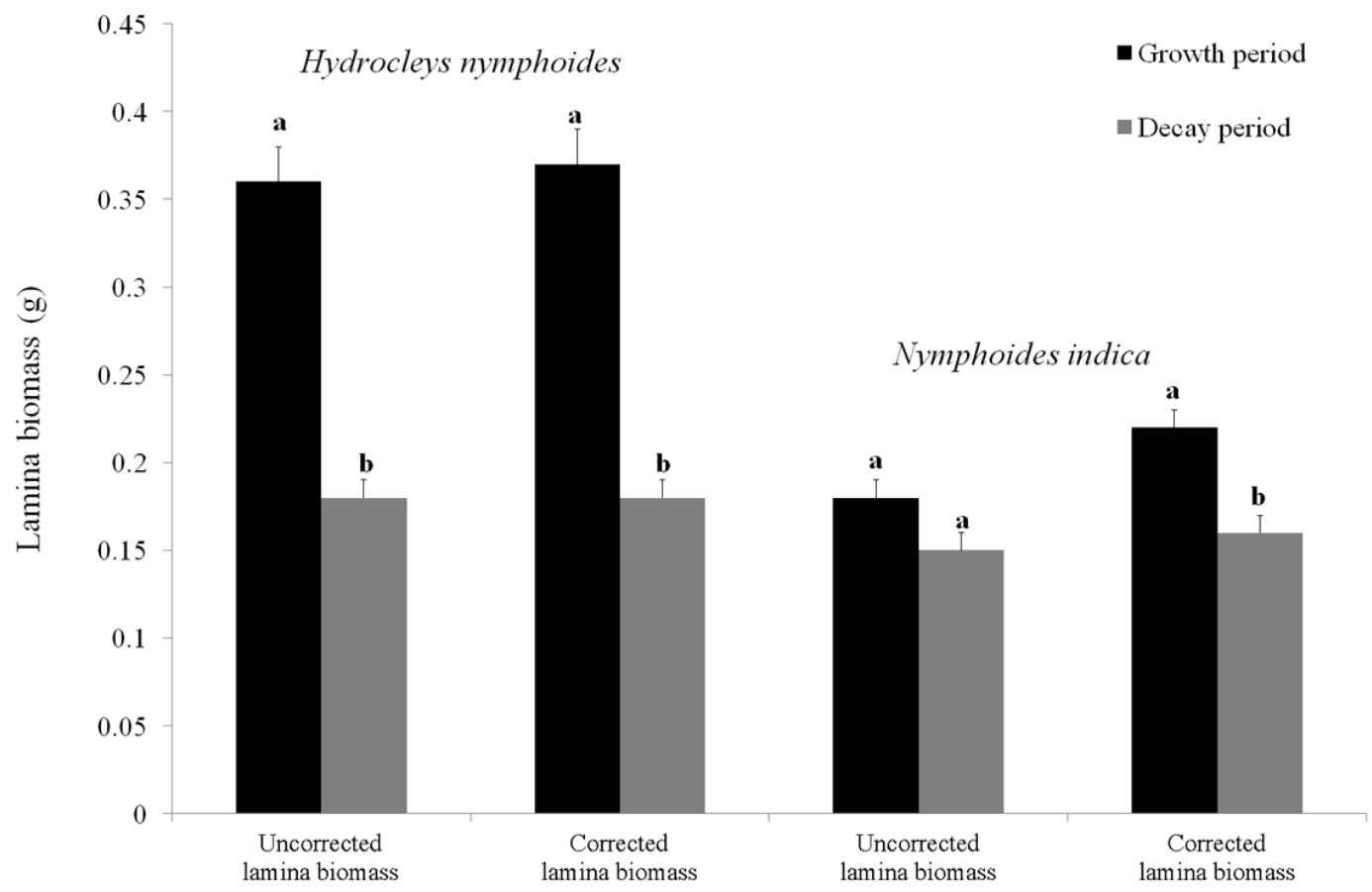

Figure 4 - The uncorrected lamina biomass and the corrected lamina per leaf lamina among floating-leaf macrophyte species in growth period y decay period. The uncorrected lamina biomass is the weight of the lamina measured directly, without including herbivorous damage. The corrected lamina biomass is the weight of the lamina adding herbivorous damage. Different letters indicate means statistically different between sampling dates.

On the other hand, the area damaged in the leaf lamina of $H$. nymphoides, $N$. prolifera and $N$. indica is lower than $26 \%$ and $16 \%$ of the damaged lamina area for Eichhornia crassipes and E. azurea leaves in the study area (Franceschini et al. 2010, 2011). This could be related to the anatomic features of leaf tissues. Gonzalez (2005) points out that, whereas floating-leaf macrophytes have starshaped sclereids and columnar sclereids, distributed in the mesophyll and the palisade parenchyma of the leaves, E. crassipes and E. azurea leaves have fewer lignified elements. These elements are directly involved in the lower palatability of plant tissues for invertebrate herbivores (Bernays and Chapman 1994).

Several floating-leaf macrophytes are known for producing alkaloids and tannins, including the Nuphar, Nymphaea and Nelumbo species (Kok et al. 1992). Lower damage registered to leaves of $H$. nymphoides and $N$. prolifera, might be the result of the high level of tannin content in these species, $3.67 \%$ and $5.40 \%$, respectively; whereas the least concentrations were found in the leaves of $N$. indica $(0.61 \%)$ in the study area (Martínez F.S. et al., unpublished data). This phenolic polymer is known for significantly reducing the palatability for herbivorous insects (Rosenthal and Berenbaum 1991).

Differences in the magnitude of herbivory such as the type of damage recorded for floating-leaf macrophyte species, holes and surface abrasions, could be the result of the different taxas of herbivores present in each macrophyte as well as the relative size and activity of the taxa of herbivores, as stated by Cronin et al. (1998). In fact, the highest values of damage by holes in relation to the surface abrasion found on N. indica and N. prolifera in the growth and decay periods may be related to the predominance of chewing herbivores with high body biomass, like Lepidoptera and Acridoidea, which were confirmed on these macrophytes 


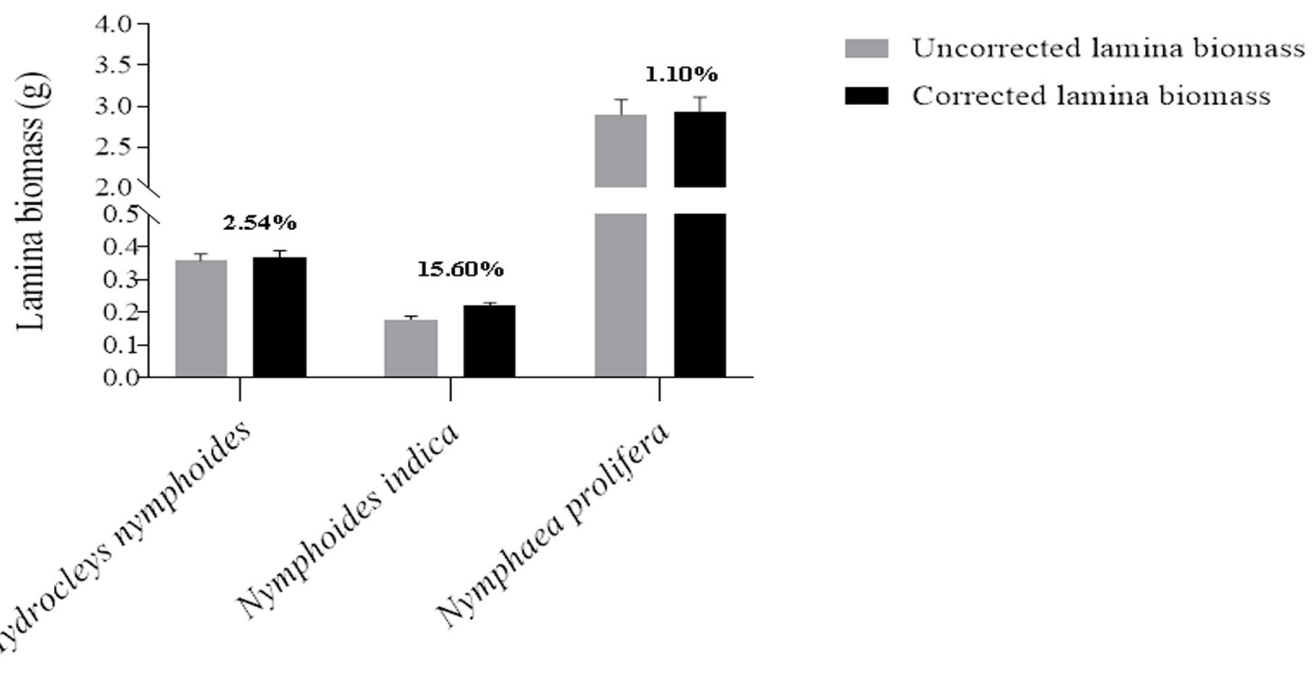

Figure 5 - The uncorrected lamina biomass and the correct lamina biomass per leaf among floating leaf macrophytes species in growth period. The uncorrected lamina biomass is the weight of the lamina measured directly, without including herbivorous damage. The corrected lamina biomass is the weight of the lamina adding herbivorous damage. $\%$ indicates biomass removed by herbivory; therefore it indicates underestimation of the leaf lamina biomass in each macrophyte species when the uncorrected lamina biomass is used.

during the sampling. In contrast, on H. nymphoides, higher damage by surface abrasion in relation to holes in both growth periods may be related to the predominance of Curculoinidae and aphids, which are herbivores with low body biomass that were observed in this macrophyte during sampling and in another study (Martínez F.S. et al., unpublished data, Franceschini et al. 2016).

\section{CORRECTED VERSUS UNCORRECTED LAMINA BIOMASS: DO ECOLOGISTS NEED A CORRECTION FACTOR TO CALCULATE THE LEAF BIOMASS OF FLOATING-LEAF MACROPHYTES?}

There is no difference in the results for $H$. nymphoides when the uncorrected lamina biomass and the corrected lamina biomass are compared throughout periods indicating that leaf biomass can be obtained through the direct dry weight of leaves; there is no need either to calculate the biomass removed by herbivores and the corrected lamina biomass. The opposite occurs with $N$. indica, where it is recommended to consider the biomass removed by herbivores to calculate plant biomass and productivity, and to use the corrected lamina biomass instead of the uncorrected lamina biomass. In fact, differences in results when the uncorrected lamina biomass and the corrected lamina biomass are compared between growth periods support this statement. In addition, herbivorous damage of $N$. indica is significant because up to $15.60 \%$ of the leaf lamina biomass and $17.69 \%$ of the lamina biomass were removed per $\mathrm{m}^{2}$ in the plant population. The importance of considering the values of corrected lamina biomass and biomass removed by herbivores in $N$. indica is consistent with the findings in E. crassipes in the study area (Franceschini et al. 2010). Therefore, for the study of biomass and productivity in the study area, we suggest the use of uncorrected lamina biomass on $H$. nymphoides, while in $N$. indica we recommend the use of corrected lamina biomass after estimating the biomass removed by herbivores.

The values of damage per lamina in $N$. indica emphasize the importance of this macrophyte as a food resource for invertebrate herbivores in the tropic webs of the studied wetlands and the role as consumer of live tissue of these invertebrate 
herbivores feeding and processing macrophyte biomass in the wetlands. The area damaged per leaf lamina in $N$. indica represents $15.60 \%$ of the foliar area, but the effect could be much higher. In fact, the area damaged by herbivores can cause alterations in the photosynthetic and productivity patterns of the leaves in an area 6 to 7 times greater than the area damaged (Zangerl et al. 2002). The low values of damage per lamina and per $\mathrm{m}^{2}$ in $H$. nymphoides and $N$. prolifera indicate that the herbivores act mainly as shredders of the living plant tissue, contributing to the decay of the leaves, which would be consumed as detritus mainly by the shredder invertebrate detritivores at the bottom of the wetlands. As $H$. nymphoides and $N$. indica are present throughout the year, it should be pointed out that they are available food resources for invertebrate herbivores during the decay period, when climatic conditions are not ideal and there is a decrease in the plant biomass and leaf density which produce a shortage of resources.

Our hypothesis that invertebrate herbivory is significant in floating-leaf macrophytes, mainly in the growth period and that the damage by herbivores should be taken into account in estimations of plant biomass of these macrophytes, must be partially accepted. Although consumption was higher in the growth period for the macrophyte species analyzed, the damage by herbivores was only significant for $N$. indica in relation to the values estimated. In addition, as high damage per lamina and per $\mathrm{m}^{2}$ of vegetation was found only on $N$. indica, the damage by herbivores should only be taken into account in estimations of plant biomass of this macrophyte species.

\section{ACKNOWLEDGMENTS}

This study was funded by the PICT 2011-2160 and PICT-2015-1910 projects FONCYT (Argentina), PI: Q001-11 project SEGECYT-UNNE (Argentina). We thank Dr. Martin Videla for the critical reading of our manuscript and Dr. Analia Lanteri for the identification of Curculionidae.

\section{REFERENCES}

ADIS J AND JUNK WJ. 2003. Feeding impact and bionomics of grasshopper Cornops aquaticum on the water hyacinth Eichhornia crassipes in the Central Amazonian floodplains. Stud Neotrop Fauna Environ 38: 245-249.

BAKKER ES, WOODB KA, PAGÈS JF, VEEND GF (CISKA), CHRISTIANEN MJA, SANTAMARÍA L, NOLET BA AND HILT S. 2016. Herbivory on freshwater and marine macrophytes: A review and perspective. Aquat Bot 135: 18-36.

BERNAYS EA AND CHAPMAN RF. 1994. Host-plant selection by phytophagous insects. Chapman \& Hall, New York, USA, 305 p.

BRAGA CE, NUNES AL, MORAIS JW AND ADIS J. 2013. Avaliação do potencial do gafanhoto Cornops aquaticum (Orthoptera) como agente de controle biológico de Eichhornia crassipes (Pontederiaceae). Interciencia 38: 590-596.

BROCK TCM AND VAN DER VELDE G. 1996. Aquatic macroinvertebrate community structure of a Nymphoides peltata-dominated and macrophyte-free site in an oxbow lake. Neth J Aquat Ecol 30: 151-163.

BRUNIARD ED. 1996. Geografía de los climas y de las formaciones vegetales. Las zonas térmicas y la vegetación natural. EUDENE, Editorial Universitaria de la Universidad Nacional del Nordeste, Corrientes, Argentina, 330 p.

CAPELLO S, MARCHESE M AND DE WYSIECKI ML. 2012. Feeding habits and trophic niche overlap of aquatic Orthoptera associated with macrophytes. Zool Stud 51: 51-58.

CAPELLO S, MARCHESE M AND DE WYSIECKI ML. 2013. Orthoptera assemblages associated with macrophytes of floodplain lakes of the Paraná River. Rev Bras Entom 57: 59-66.

COLEY PD, BRYANT JP AND CHAPIN FS 3rd. 1985. Resource availability and plant antiherbivore defense. Science 230(4728): 895-899.

CRONIN G, WISSING KD AND LODGE DM. 1998. Comparative feeding selectivity of herbivorous insect on water lilies: aquatic vs. semi-terrestrial insect and submersed vs. floating leaves. Freshw Biol 39: 243-357.

DI RIENZO JA, CASANOVES F, BALZARINI MG, GONZALEZ L, TABLADA M AND ROBLEDO CW. 2016. InfoStat versión 2016. Grupo InfoStat, FCA, Universidad Nacional de Córdoba, Argentina. http://www. infostat.com.ar.

ESTEVES F. 2011. Fundamentos de Limnología, $3^{\mathrm{a}}$ ed., Editora Interciência. Rio de Janeiro, Brasil, 790 p. 
FOOTTIT RG AND ADLER PH. 2009. Insect biodiversity: Science and Society. Blackwell Publishing Ltd, UK, 656 p.

FRANCESCHINI MC, DE WYISIECKI ML AND POI A. 2013. Age structure and feeding of the Neotropical grasshopper Cornops aquaticum (Bruner) (Orthoptera: Acrididae) on water hyacinth. Neotrop Entom 42: 344350.

FRANCESCHINI MC, MARTÍNEZ FS, MURPHY K, KENNEDY M, WILLEMS F AND SICHINGABULA H. 2016 ¿Es realmente baja la herbivoría y hay pocos herbívoros en los humedales subtropicales? VII Congreso Argentino de Limnología. San Miguel de Tucuman, Argentina. Acta Zool Lilloana 60(Supl): 32-33.

FRANCESCHINI MC, NEIFF JJ AND AMEDEGNATO C. 2011. The Oxycaryum cubense floating mat as refuge of Cornops aquaticum (Orthoptera: Acrididae), a new control agent of the water hyacinth. Stud Neotrop Fauna Environ 46: $203-210$.

FRANCESCHINI MC, POI DE NEIFF A AND GALASSI ME. 2010. Is the biomass of water hyacinth lost through herbivory in native areas important? Aquat Bot 92: 250-256.

GONZALEZ AM. 2005. Anatomía del vástago en especies selectas de plantas hidrófilas. Flora de Iberá. In: Arbo MM and Tressens SG (Eds), EUDENE, Editorial Universitaria de la Universidad Nacional del Nordeste. Corrientes, Argentina, p. 431-450.

HAYNES RR. 2000. Limnocharitacae Vol. 22. In: Flora of North America Editorial Committee, Flora of North America North of Mexico Oxford Univ. Press, New York, p. 5-6.

HUNT-JOSHI TR, BLOSSEY B AND ROOT RB. 2004. Root and leaf herbivory on Lythrum salicaria: implications for plant performance and communities. Ecol Appl 14: 15741589.

KOK CJ, HOF CHJ, LENSSEN JPM AND VAN DER VELDE G. 1992. The influence of $\mathrm{pH}$ on concentrations of protein and phenolics and resourse quality of decomposing floating leaf material of Nymphaea alba L. (Nymphaeaceae) for detritivore Asellus aquaticus (L.). Oecologia 91: 229-234.

LABANDEIRA CC. 1998. Early history of arthropods and vascular plants associations. Annu Rev Earth Planet Sci 26: 329-377.

LALLANA VH. 2005. Lista de malezas del cultivo de arroz en Entre Ríos, Argentina. Ecosistemas 14: 162-167.

MARTÍNEZ FS, FRANCESCHINI MC AND POI A. 2013. Preferencia alimentaria de Neochetina eichhorniae (Coleoptera: Curculionidae) en plantas acuáticas de diferente valor nutritivo. Rev Col Entomol 39: 81-87.

NACHTRIEB JG, GRODOWITZ MJ AND SMART RM. 2011. Impact of invertebrates on three aquatic macrophytes: American pondweed, Illinois pondweed and Mexican water lily. J Aquat Plant Manag 49: 32-36.
NEIFF JJ, CASCO SL AND POI DE NEIFF A. 2008. Response of Eichhornia crassipes (Pontederiaceae) to water level fluctuations in two lakes with different connectivity in the Paraná River floodplain. Rev Biol Trop 56: 613-623.

NUNES KA, CASSIN CM AND KOTANEN PM. 2016. Variation in herbivory along a latitudinal gradient for native and exotic Asteraceae. Plant Ecol 217: 481-493.

OENDUFF R. 1969. Neotropical Nymphoides (Menyanthaceae): Meso-American and west indian species. Brittonia 21: 346-352.

PALMA-SILVA C, ALBERTONI EF, TRINDADE CR AND OLIVEIRA SS. 2008. Nymphoides indica (L.) O. Kuntze (Menyanthaceae) em um pequeno lago raso subtropical (Rio Grande, RS). Iheringia Ser Bot 63: 249-256.

PEETERS PJ, SANSO G AND READ J. 2007. Leaf biomechanical properties and the densities of herbivorous insect guilds. Func Ecol 21(2): 246-255.

POI DE NEIFF AS AND CASCO SL. 2003. Biological agents that accelerate winter decay of Eichhornia crassipes Mart. Solms in northeastern Argentina. In: Thomaz SM and Bini LM (Eds), Ecologia e manejo de macrófitas aquáticas. Maringá, Brasil, p. 127-144.

RASBAND WS. 2016. ImageJ, U S National Institutes of Health, Bethesda, Maryland, USA, http://imagej.nih.gov/ ij/. Accessed on July 2, 2016.

ROSENTHAL GA AND BERENBAUM MR. 1991. Herbivores. Their interactions with secondary plant metabolites. Vol I: The chemical participants. Academic Press INC, New York, USA, 457 p.

SILVA JO, ESPÍRITO-SANTO MM AND MELO GA. 2012. Herbivory on Handroanthus ochraceus (Bignoniaceae) along a successional gradient in a tropical dry forest. Arthropod Plant Interact 6(1): 45-57.

SOSA AJ, CORDO HA AND SACCO J. 2007. Preliminary evaluation of Megamelus scutellaris Berg (Hemiptera: Delphacidae), a candidate for biological control of waterhyacinth. Biol Contr 42(2): 129-138.

VAN DER VELDE G, GIESEN TG AND VAN DER HEIJDEN LA. 1979. Structure, biomass and seasonal changes in the biomass of Nymphoides peltata (Gmel.) O. Kuntze (Menyanthaceae) a preliminary study. Aquat Bot 7: 279-300.

VAN DER VELDE G AND VAN DER HEIJDEN LA. 1985. Initial decomposition of floating leaves of Nymphoides peltata (Gmel.) O. Kuntze (Menyanthaceae) in relation to their age with special attencion to the role of herbivores. Verh Internat Verein Limnol 22: 2937-2941.

VAN DER VELDE G, VAN DER HEIJDEN LA, VAN GRUNSVEN PAJ AND BEXKENS PMM. 1982. Initial decomposition of Nymphoides peltata (Gmel.) O. Kuntze (Menyanthaceae), as studied by the leaf-marking method. Hydrobiol Bull 16: 51-60. 
WANTZEN KM, RAMIREZ A AND WINEMILLER KO. 2006. New vistas in Neotropical stream ecology Preface. J North Am Benthol Soc 25: 61-65.

WIBMER GJ. 1989. Revision of the weevil genus Tyloderma Say (Col.: Curculionidae) in Mexico, Central America, South America, and the West Indies. Evol Monograph 11: 1-118.

WIERSEMA JH. 1987. A monograph of Nymphaea subgenus Hydrocallis (Nymphaeaceae). System Bot Monographs 16: 1-112.
WOOD KA, O'HARE MT, MCDONALD C, SEARLE KR, DAUNT F AND STILLMAN RA. 2017. Herbivore regulation of plant abundance in aquatic ecosystems. Biol Rev 92: 1128-1141.

ZANGERL AR, HAMILTON JG, MILLER TJ, CROFTS AR, OXBOROUGH K, BERENBAUM MR AND DE LUCIA EH. 2002. Impact of folivory on photosynthesis is greater than the sum of its holes. Proc Natl Acad Sci 99(2): 10881091. 